\title{
Revisiting Cold War Ideology in the Secure City: Towards a Political Economy of Urbicide
}

\author{
10:2 |@ 2007 Michael Dudley
}

If civilized society has not yet outgrown war...it is partly because the city itself in its structure and institutions continues to give war both a durable concrete form and a magical pretext for existence.

-- Lewis Mumford ${ }^{1}$

\subsection{Introduction: Returning to the City of Fear}

1. In addition to providing the justification for an ongoing 'war on terror', the attacks on the World Trade Center and the Pentagon triggered an intense discussion within the city planning and architecture fields over how best to plan for the "secure city ${ }^{2}$." Within days of the attacks (and in the months and years that followed) American cities -- particularly those with a large governmental presence -- saw a rapid, grim transformation:

2. "To appreciate how America has changed since 9/11, walk slowly through any major city. What you'll see dotting the landscape is the physical embodiment of fear. Security installations put up after the attacks continue to block public access and wrangle pedestrian traffic. Outside Manhattan's Port Authority Bus Terminal, garish purple planters menace rush-hour pedestrian traffic. The gigantic planters have abandoned all horticultural ambition, many of them blooming with nothing more than trash and untilled dirt. "French barriers," steel-grate barricades meant for controlling crowds, ring many landmark sites -- including San Francisco's Transamerica Building -- like beefy bodyguards protecting starlets. Then there are the bollards, the cylindrical vehicle-blocking posts that are so pervasive you wonder if they've mastered asexual reproduction. In Washington, bollards surround everything $\underline{3}$."

3. This is the new American "securescape", the goals of which are mostly hostile to tenets of mainstream urban design. As Vale (2005) explains, where New Urbanists seek narrower streets, hidden parking and enhanced pedestrian access, the new imperative for securitization promotes massive building setbacks, surface parking and controlled pedestrian access to key sites $^{4}$. But these effects are not just localized; they are regional. This is particularly true in the case of Virginia, where workplaces for Department of Defense personnel have been decanted into suburbs, to constitute what Natsios refers to as "national security sprawl" $\underline{5}$. 
4. It is as if the new security aesthetic, in securing public space, "means securing space from the public, rather than for it" ${ }^{\prime \prime}$-- an imperative which extends from the public realm to the private: "The single-family home is a rich lode of sensitive information...Sprawl's complex information space has become captive to panoptic schemes of 'multiple cartographies of surveillance"'"?

5. The extent to which security has become a driving factor in contemporary American urbanism is such that "security experts are acting as the associate architects on every project

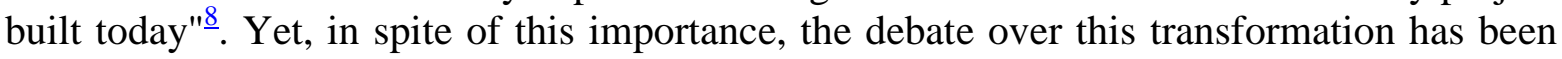
rather circumscribed: it has been largely of a technical, aesthetic and instrumental nature: that is, more concerned with how best to achieve more secure cities and in a more livable fashion, rather than questioning in a comprehensive manner the rationales for and contexts of the urban security project itself, and -- given these rationales and contexts -- its likely outcome. This paper proposes that such an inquiry may be best joined by means of an historical analogy.

6. The present imperatives to make cities secure against terrorist attacks in the post-9/11 era have a compelling precedent in the Cold War "defensive dispersal" movement, which was a highly influential discourse within the city planning profession in the late 1940s and 1950s that sought to redesign cities to reduce the threat of nuclear weapons ${ }^{9}$. The particular arguments of the defensive dispersal movement and its place within the history of both the policy sciences in general and city planning discourse in particular have been explored elsewhere both by the present author and others $\frac{10}{}$. What is of interest here is not a comparative analysis between the claims, principles and strategies of defensive dispersal writers and their post 9/11 counterparts, but rather an examination of the ideological contexts in which both discourses are set. This paper asks, what is the relationship of these discourses to the dominant geo-political ideologies of their respective eras?

7. Just as defensive dispersal literature cannot be adequately understood without reference to Cold War intellectual culture -- specifically the rigorous (and ongoing) project of nuclear normalization in which the development and use of nuclear weapons on civilian populations were rendered "acceptable" in a democratic society ${ }^{11}$-- so too must contemporary efforts to promote urban security be seen as a specific facet of a highly problematic "war on terror", the origins, purpose and resolution of which are fraught with controversy and steeped in neoconservative and neo-imperial ideologies.

8. We should first deconstruct these two movements so that we may understand their parallels and divergences. Both are products of essentially the same proponents (city planning theorists, practitioners, policy analysts, social scientists and non-specialist observers), and both attempt to address their respective socio-political and technological crises by proposing alterations to the urban environment. As well, both discourses translate what had been ongoing debates in urban policy and planning into new contexts: early postwar writers saw the nuclear threat as a new way to promote existing concepts (such as regional planning) through satellite cities and other forms of decentralization, while present arguments and proposals for urban security emphasize longstanding crime prevention through environmental design principles (CPTED) $)^{\frac{12}{2}}$.

9. In both cases it is also necessary to distinguish between the contributions of design professionals on the one hand, and the activities of real estate, government and corporate interests on the other, in terms of privately pursuing locational decisions and defensive architectural embellishments independent of policy initiatives. While there has been a great 
deal of writing about urban security from all quarters over the past six years, an array of adhoc responses have been thrown up around public buildings (e.g., jersey barriers) with predictable negative results for the public realm ${ }^{13}$-- much of it done without the involvement of city planners. The actual setting out of official guidelines on the part of the American Planning Association dates only from January 2005. In other words, city planners have been largely left out of the actual implementation of the secure city, and -- much like their Cold War predecessors -- are striving to make their profession relevant in the new political climate.

10. Where the two literatures diverge is in their attitudes towards the future. A striking and recurring element in much of the Cold War dispersal literature is a kind of salvation motif: An earnest belief that these plans, while devised in response to a terrible threat, would someday result in cities

infinitely better than anything we have yet seen...most of us will not live to witness the final achievement, but we can at least have the satisfaction of a part in the creation of the efficient, comfortable, beautiful cities and towns which will comprise the metropolitan regions of the next century ${ }^{14}$.

11. Someday, it was believed,

the present fearful...threat hanging over the great city will have been turned into so great a blessing that men, looking backward in an age in which atomic power shall have been fully harnessed to peaceful ends, will say that the greatest benefit which flowed from the explosion at Los Alamos (sic) was the enforced rebuilding of our urban centers 15 .

12. This is not a theme we see much of in the literature of -- and designs for -- the secure city. There is no modernist optimism that the city of the future will be improved on a large scale by enhanced attention to security, nor is there a sense that there will be a brighter and terror-free future for our grandchildren. This unstated pessimism was made grimly manifest in the penultimate design for Manhattan's Freedom Tower, which was to have featured a 200-foot tall and fortress-like base which would have been equally impervious to both truck bombs and a dignified public realm ${ }^{16}$. Sensing that the urban security movement had reached some sort of aesthetic nadir, critics and members of the public reacted with considerable hostility, and in June 2006 it was announced that the visual harshness of the base would be softened by a screen of glass prisms (Dunlap and Collins 2006). As well, with the $6^{\text {th }}$ anniversary of the 9/11 attacks looming, urban designers are moving towards softer, more aesthetically-pleasing and non-obtrusive security measures in an effort to improve the quality of public spaces $\frac{17}{}$.

13. But this very movement towards disguising security measures reveals that the semiotics of secure spaces are more important than their actual functioning: for while architects and urban designers have sought for ways to make security measures more attractive -- or even invisible -- security consultants and property owners are objecting: "Indeed one of the paradoxes of security infrastructure is that sometimes appearance can be more important than actual strength. A Tiger Trap concrete surfaces which are sufficiently strong to support pedestrians but will collapse under the weight of a truck is more effective at blocking a truck 
bomber than a Jersey barrier, but a Jersey barrier looks more menacing. $\underline{18}^{\prime \prime}$

14. As we move from ad-hoc barriers to more permanent interventions, we must acknowledge then that their very permanence assumes that the country that is constructing them is not -- and may never be -- free from its fears -- that the "war on terror" may, in fact, be a war without end. And if the rhetorical value of the target-hardened environment is indeed paramount, then it becomes essential to decode what these semiotics tell us about the role of the City in the political economy of the "war on terror."

15. For these reasons, I will develop further the parallels that may be found between our own era and that of "defensive dispersal."

\subsection{Defensive Dispersal}

16. The primary tenets of defensive dispersal were regional satellite cities (variations on Ebenezer Howard's Garden City); the need to disperse industrial capacity out of central cities; the need for increased freeway capacity; and a "thinning out" of existing cities through demolition and renewal. Extreme versions of these ideas included "donut", radial and linear cities. $\frac{19}{}$

17. Fear of the atomic bomb actually exerted considerable influence over three interrelated design projects: the design of houses and other buildings, the disposition of buildings within the city, and the design and placement of fallout shelters within homes and public buildings. The first was more properly the domain of architects (and was in fact the subject of a "Conference on Building in the Atomic Age" held at MIT in June of $1952^{20}$, the second of city planners, and the third, while referred to in both literatures, was of such paramount importance to government civil defense objectives, and subject to such unsettling public attention, that it constituted a "craze. ${ }^{21}$ " Because of these related design goals, defensive dispersal should be seen as a more specialized theme of the civil defense program.

18. It is worth mentioning that for the 20-year period after the Second World War, planning was essentially viewed as "architecture writ large", and many planners were trained $\operatorname{architects}^{22}$. Both the American Institute of Architects and the American Institute of Planners invested a great deal of energy in the civil defense aspects of design ("Pros and cons" 1951). The American Institute of Architects' involvement in civil defense matters extended so deeply that member architects actually participated in at least one nuclear test explosion, Operation Cue (May $5^{\text {th }}$ 1955), which involved the construction -- and subsequent obliteration -- of a number of buildings, including typical residential homes ${ }^{23}$. This enmeshment with the national security apparatus on the part of the design and policy professions was mirrored in the rhetoric of defensive dispersal.

\subsection{Rhetorically Situating the Defensive Dispersal and Post 9/11 Urban Security Movements}

19. Defensive dispersal was a product of a highly "nuclearized" society in which the imperatives of the nuclear arms race had saturated and influenced almost every aspect of American life ${ }^{24}$. As such, it served to perpetuate the Cold War ideology to which it was inextricably bound. Planners sought to "contain" the irrational and make it rational. Dispersal was essentially "fantasy planning" 25 geared more for rhetorical than practical purposes; and it simultaneously sought to expiate Americans' guilt over Hiroshima and Nagasaki, while contributing to the project of making nuclear war thinkable. As we shall see, each of these rhetorical positionings has its parallel in the post-9/11 planning world. 


\subsubsection{Fantasy Planning}

20. In his 1999 book, Mission Improbable: Using Fantasy Documents to Tame Disaster, Lee Clarke examines how organizations -- corporations and government alike -- often formulate plans that are based on untestable and unrealistic assumptions, have little hope of being implemented in real-life situations, and are, indeed, so far removed from reality that Clarke has no hesitation in referring to them as "fantasy documents." Not insignificantly, the plans under discussion revolve around disastrous events such as oil spills, natural disasters, nuclear meltdowns and nuclear war. A classic example of this sort of planning cited by Clarke was the initiative taken by the U.S. postal service during the Administration of President Jimmy Carter to plan for the continuation of mail delivery after a nuclear war. Considerable effort was spent in this plan to describe the chain of command in the postal service, and how employees would assist in the completion of change of address cards for relocated populations. The assumptions underlying this exercise were so unbelievable that it was subject to Congressional inquiry ${ }^{26}$.

21. For Clarke, most disaster plans are surely not intended by their architects to be implemented, let alone succeed in their aims. Their value is purely symbolic, in that they are intended to impart some sense of rationality, expertise and control on the part of the organizations presenting the plans. In other words, fantasy disaster planning documents are prepared and presented solely for their rhetorical power. The intended result is that the given danger is normalized: the intended audience is led to believe that the most catastrophic contingencies have been foreseen and planned for, and that the risks under consideration are ultimately acceptable ones ${ }^{27}$.

22. Although Clarke doesn't refer to defensive dispersal literature in his book, it is clear that, given the characteristics he provides for "fantasy documents", defensive dispersal plans were also fantastic and at least as useful for their symbolic and rhetorical power as for their practicality. While some of the more ambitious dispersal plans (building linear and donutlike cities and relocating millions of people, for instance) were acknowledged at the time to be hopelessly expensive, the dispersal options presented in the massive civil defence study Project East River ${ }^{28}$ and elsewhere (to accelerate contemporary trends towards low density development) were clearly practical and achievable. However practical such plans were, one cannot disguise that their ostensible purpose -- to reduce the danger from nuclear weapons -was utterly without hope.

23. In the post-9/11 era, too, we have seen an effort to make it appear that governments and other authorities are doing something -- anything -- to make Americans more secure. Many of these efforts, when not actually inane (i.e., colour-coded terror alerts), have in reality actually done more to unnerve Americans. Yet, as the Hurricane Katrina debacle demonstrated, the ability of governments to plan for and address large-scale emergencies is almost totally underdeveloped and dysfunctional, despite the days' worth of notice hurricanes afford; which naturally begged the question of how the Federal government could possibly hope to respond to an actual attack by terrorists who show no such courtesy.

24. All the manuals, conferences, articles, websites and planning documents geared to addressing security in the post-9/11 era will likely prove to be of little more instrumental effect than were their Cold War ancestors -- but will nonetheless have served their rhetorical purpose. 


\subsubsection{Rationalizing the Irrational}

25. In the nuclear threat the rational and scientific profession of city planning found a planning problem that constituted the ultimate challenge for rational approaches. Yet this rationality belied what ought to have been a patent truth: what was being rationalized by dispersal planners (a reasoned and constructive approach to living with atomic weapons) was quite irrational. No amount of urban re-engineering would have been able to prevent massive losses of life and the lethal radioactive contamination of most of the planet. Even on its own terms, the thesis that satellite cities would reduce the nuclear vulnerability of the country was an exceedingly specious one. In housing the newly dispersed war industries, satellites would not only become the more desirable target, but in their profusion would require a determined enemy to stockpile ever more atomic weapons. And in considering only the effects of heat and blast -- which could be ameliorated by distance -- and neglecting the long-term consequences of radiation and social chaos, dispersal planners rationally "contained" a hypothetical threat beyond any point of contact with reality.

26. For Lifton and Falk (1982), such faith in technically rational approaches to nuclear weapons constitutes embedded "nuclearism" and an "illusion of rationality":

27. The illusion is of a "systems rationality" -- of a whole structure of elements, each in "logical" relation to the other components and to the whole. We are dealing here with nothing less than the logic of madness -- of a social madness and collective "mad fantasy"...For the builders of such "rational systems"...are, like the rest of us, confronted by an image they really do not know how to cope with, and seek desperately to call forth, however erroneously, the modern virtue of reason ${ }^{29}$.

28. While all wars are to a greater or lesser degree irrational, the "war on terrorism" must rank among the most hopeless and irrational exercise in which any nation has engaged. Attempting to secure cities through apparent interventions in the built environment, if nothing else, makes this abstract war tangible and -- literally -- concrete. The irrational is thus, to a degree, rationalized.

\subsubsection{Expiating Guilt}

29. It is an historical irony that it was Americans, of all people, for whom the atomic age should have brought such extreme manifestations of public anxiety. Pearl Harbor aside, the United States had proved virtually unassailable militarily, was physically unscathed by World War II, and for four years after the war possessed a nuclear monopoly. Even once the Soviet Union did develop its own atomic weapons, it was years before that country had the capability to launch them across the planet or even had enough quantities to compete with America's stockpile. Why then, Boyer asks, did Americans so "quickly transmute the devastation of Hiroshima into visions of American cities in smoldering ruins....and envision themselves not a potential threat to other peoples, but as potential victims?" ${ }^{30}$ For Lifton and Mitchell, the answer is an unsettling one:

30. Americans were perpetrators of Hiroshima rather than victims...Even victims can struggle with feelings of guilt, but perpetrators of such an event are likely to expend enormous energy in fending off self-doubt. One can do that either by investing the event with virtue...or by seeking to divest oneself of the perpetrator's role and take on that of the victim $^{31}$. 
31. This expresses perfectly what the present author believes was one of the most psychologically valuable rhetorical functions of the defensive dispersal movement. Like the civil defense program of which it was a part, it relentlessly focused the attention of Americans on their own potential for victimhood. Defensive dispersal and civil defense encouraged Americans to expend their emotional energy contemplating how their own cities might be bombed. As such it was easier for the nation as a whole to forget that it was America that had used the bombs against two cities with almost a half a million noncombatants between them. If such a past could thus be rationalized, then it was a very short psychological distance to contemplating using such bombs again.

32. Of course, Americans have now become victims, and have watched their own buildings collapsing and burning. Unfortunately, many Americans -- urged on by their leaders and a compliant mass media -- have so embraced their new status of victimhood that the events of 9/11 are being used to justify any and all acts of war, torture and terror delivered in kind to whomever has the misfortune of being the declared enemy du jour. This sense of victimhood -- and the omnipresent fear of potential victimhood -- has had the effect of generating political consensus on so many fronts that any foray beyond received conventional wisdom is viewed as unthinkable.

\subsubsection{Planning for Security as Conventional Wisdom}

33. Cold War defensive dispersal became part of the assumptions of planners because it was portrayed as conventional wisdom. In its 1953 endorsement of Project East River, the American Institute of Planners used some particularly potent language to stress the essential correctness of dispersal principles:

34. The American Institute of Planners does not claim competence in military measures of national defense, but it holds this fact self-evident, that the best way to prevent attacks upon this country is to deprive potential enemies of targets that will make such attacks profitable to them....plain common sense dictates that it should be remedied with all possible $\operatorname{dispatch}^{\underline{32}}$.

35. Readers at all familiar with American history should recognize the allusion in the first sentence, one which can hardly have been an accident. It is, of course, an echo of the second paragraph of one of the most hallowed of American documents, the Declaration of Independence: "We hold these truths to be self-evident, that all men are created equal..." Such an argument would have been difficult to refute, particularly during a time of such ferocious "anticommunist" purges.

36. The statement also calls defensive dispersal "plain common sense." Clearly, by 1953, the concept of urban design being subject to the needs of the atomic age was a familiar one. The sheer proliferation of literature concerning the needs for dispersing industry and population ${ }^{33}$ indicates that defensive dispersal was rapidly becoming "embedded" on a number of levels: amongst city planners, atomic scientists, military strategists, city councils, engineers, politicians, real estate agents and ordinary laypersons.

37. What is interesting about the American Planning Association's post 9/11 Policy Guide on Security is that it, too, seems so reasonable -- even slightly contrarian, in that it seeks to ameliorate the negative impact of so much of the early response to $9 / 11$ in the built environment, by stressing that secure cities must also be aesthetically pleasing (admonitions that by mid-2006 appear to be bearing fruit $\mathrm{in}^{34}$. It also warns against vacating cities for the 
hinterlands and thus accelerating sprawl. Safe cities, according to the APA, need people walking around them at all hours -- and such a goal is not served by massive setbacks and barriers. The APA advocates adherence to longstanding principles of CPTED, which they maintain will do much to achieve anti-terror objectives in the built environment; and who could argue? Some ideas concerning defensible space -- as Newman ${ }^{35}$ points out -- have been common practice in vernacular architecture across cultures and centuries.

38. The trouble with the urban security project is not to be found in defensible design principles or in disaster preparedness, both of which are, on their own terms, important and necessary considerations for any community. Rather, it lies in urban securitization's disturbing links to neo-imperial power, and in its contribution to the discourse of militarization.

\subsubsection{Planning with Authority}

39. To the extent that city planners during the Cold War participated in a project to render nuclear war thinkable, winnable and rational, they can be said to have been guilty of, at best, wishful thinking and naivete. A dimmer view would hold that the defensive dispersal project was, in fact, one of misinformation, to "keep facts from a public which must be protected, to appear to be doing something about civil defence, and to minimize in the public mind the extent of the destruction likely to accompany an all-out war. ${ }^{36}$ "

40. At its worst, however, one can view this chapter of planning history as something far more complex and frightening: one in which a profession was, by virtue of its close and actively sought relationship with federal authorities, a partner in the war-making apparatus of the United States. To cite some examples: The Board of Governors of the American Institute of Planners offered "all the facilities of our Institute and its members" to the National Security Resources Board Chairman and the director of Selective Service "for defense and for military purposes" River under the aegis of the Department of Defense, the National Security Resources Board and the Federal Civil Defense Administration; and East River members formed a "Summer Study Group" with the concurrent Project Lincoln to look at linking civil defence with the problem of continental air defence and early warning systems $\frac{38}{}$. The Board of Governors of the AIP then officially endorsed the findings of East River. Recall, too, that in 1955 the American Institute of Architects actually participated in nuclear tests.

41. Since 9/11, this pattern has been repeated: in order to produce the 2005 report, Planning for a Disaster Resistant Community, the American Planning Association ${ }^{39}$ worked closely with both the Department of Homeland Security (DHS) and the Federal Emergency Management Agency (FEMA). DHS has become a monster agency, subsuming over 100 previous federal entities, including FEMA. It has also, of course, been an active force behind the "war on terror" and its concomitant attrition of domestic civil liberties. Through DHS,

information can be collected on any dissenter, American citizen or not, violent or not. The classification of recent peace marches and protests as "terrorist events" within DOD and FEMA documents is one example of the dangerous potential of these mandates...As part of Homeland Security, the PATRIOT Act of 2001 allows the government increased and unprecedented access to the lives of American citizens and represents an unrestrained 
imposition on their civil liberties. ...Under section 501, a U.S. citizen engaging in lawful activity can be picked off the streets or from home and taken to a secret military tribunal with no access to or notification of a lawyer, the press, or family... One proposed option is that any violation of Federal or State law could designate a U.S. citizen as an 'enemy combatant' and allow him or her to be stripped of citizenship ${ }^{40}$.

42. It should be noted that the APA's partnership with FEMA predates $9 / 11$ by a number of years, and, frankly, if the APA is to participate at all in disaster planning at a Federal level, both FEMA and DHS are the agencies with whom they must work. Yet, the profession of city planning has spent the last few decades redefining itself from that of a technocratic, topdown realm of the "expert" to that of a profession that empowers communities, and encourages citizen participation, thus enhancing local democracy ${ }^{41}$. By collaborating with government agencies so integral to the imperial fantasies of the Bush administration, and that, as a matter of course, hold so little respect for democratic principles, members of the American Planning Association may, in the case of a Federal emergency, find themselves participating in measures with which they may be quite at odds ${ }^{42}$.

43. In this context, post $9 / 11$ planning discourse concerning urban security remains very much subservient to (and supportive of) the dominant power elites, and with few exceptions ${ }^{43}$ makes no effort to question the relationship between planning activities and the irrational, hyperviolent "war on terror."

44. Yet, the artifacts of the secure city cannot be seen solely on their own terms, but are inseparable from the processes laying waste to the cities of the Middle East ${ }^{44}$. Massive securitization lends powerful support to the "imaginative geographies" ${ }^{45}$ of the "terror city hierarchy" ${ }^{46}$ in which domestic cities ("the homeland') are conceived of as places to be defended against the mysterious "other" -- the cities of whom may be destroyed with equanimity.

45. All of these discursive functionings of the secure city are, furthermore, predicated on some highly significant and supposedly a posteriori assumptions: that terrorists are going to strike again; that the West is at war with radical Islam; and that we are engaged in a "clash of civilizations" $\underline{\text { 4 }}$. These assumptions are, as we shall see, premised on extremely problematic foundations.

\subsection{Ontological and Epistemological Foundations}

46. Theories about how to save the Western city from potential harm have emerged from terrible circumstances in 1945 and in 2001, but paradoxically both the atomic bombings of Hiroshima and Nagasaki, and the 9/11 events, are at once culturally omnipresent and invisible. While these events have held their respective eras rapt in horrified fascination, remarkably little was -- or is -- known about them. In terms of cause, agency, process and consequence it may fairly be said that the nuclear attacks in Japan and the localized destruction in New York and Washington D.C. remain entirely mysterious, at least to most Americans. It should be stressed that, in both eras, these informational lacunae were not accidental.

47. After the atomic bombings, the United States government both as an occupying force and for domestic purposes rigorously censored information and images concerning the 
bombings:

Early newspaper stories from Hiroshima were censored by the U.S. military; the first account from Nagasaki was killed entirely. Authorities at first denied, then downplayed, the fact that thousands of survivors were dying from radiation disease. The military confiscated all pictures taken by Japanese photographers in the atomic cities, and none was published in the United States until 1952. That the bomb had killed American POWs in Hiroshima and Nagasaki was denied for nearly forty years. Documents and decoded Japanese cables that raised doubts about Truman's decision were classified for decades (some still are). Even a Hollywood film on the first bomb was heavily revised, under orders from the Truman White House...Hidden from the beginning, Hiroshima sank, unconfronted and unresolved, into the depths of American awareness. As early as 1946, the writer Mary McCarthy was calling Hiroshima "a hole in human history.

48. In addition to these restrictions against Allied reporting, postwar censorship codes in occupied Japan forbade the Japanese themselves from mentioning the atomic bombings, nor were writers allowed to even acknowledge in print that these proscriptions existed ${ }^{49}$. Even the decision on the part of the Truman Administration to use the atomic bomb has been obfuscated to the point that historians are still arguing over whether or not the bombings were necessary at all or if their use signaled the start of the Cold War rather than the end of an existing war $^{50}$. These efforts have continued into our own era, the most dramatic example being the Smithsonian Institute exhibit in 1995 which attempted to portray a full and realistic account but, barraged by conservative media and veterans' groups was reduced to a single plaque and half a fuselage of the B-29 the Enola Gay ${ }^{51}$.

49. Similarly, the events of $9 / 11$ have also been so intensely politicized and abstracted in the service of an imperial presidency that they are one of the most intensely contested elements of the contemporary American political landscape ${ }^{\frac{52}{2}}$. They have constituted the metanarrative for the entire Neo-Conservative enterprise, and are evoked to shut down any form of opposition to administration policies. As a result, the Bush Administration and the Republican "noise machine" $\underline{53}$ have so polluted the public arena with mindless absolutisms that it is not too much to say that George W. Bush has become a truly postmodern President, in that there appears to no longer be any "truth" but what his Administration "creates. .54 " Any effort to question the nature and origins of 9/11, or the assumptions underlying the "war on terror" are deemed anti-American. Even as seemingly rational a question as "why do they

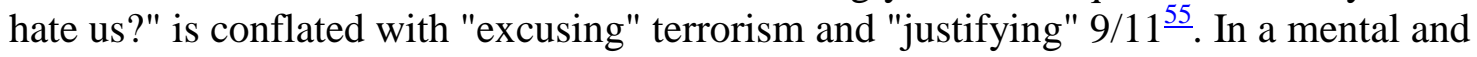
cultural environment in which asking questions about the direction of one's national life can be an act of treason, there is little hope that real knowledge of the national purpose may be gained. Because of this ontological and epistemological vacuum, we should not be surprised that the "homeland security" industrial complex is growing in size, influence and power.

50. Inextricably bound with these troubling threats to American democracy is the effort to secure buildings, networks and cities against this ill-defined but politically invaluable terrorist threat. It is almost as if, in the absence of self-knowledge and any means of attaining it, American society appears to require something physically manifested in order to reconcile itself to a new reality. In other words, the built environment must be so ordered 
that it may compensate for a disordered mental and civic environment, rent as they are by confusion, fear and ideologically-laden, unverifiable claims. In the absence of certainty, American society is creating proxies in the form of jersey barriers, massive setbacks, bollards and forests of surveillance cameras.

51. What this points to is the political economy of urbicide -- not only as an actual act of urban destruction, but as a concept, an idea, and a massively publicized potentiality wielded by the state before its own citizens for the purpose of thought control.

52. Simply put, the potential for urban destruction serves a central role in the acquisition and maintenance of power by the neo-imperial state. Not incidentally, the threat of urbicide is also contributing to new forms of capital accumulation on the part of growth machine elites, as deficit-financed federal investments in the military industrial complex are serving the economic interests of those corporations close to the circle of power ${ }^{56}$. This was just as true in the era of defensive dispersal, when the massive Interstate and "Defense" Highway system was built (much to the delight of the so-called "Road Gang", the politically-connected automobile, oil and construction industries), as is it now, when crony corporations like Halliburton are granted no-bid contracts in Iraq and Louisiana to rebuild cities devastated by Bush Administration policies.

\subsection{Conclusion: Towards a Political Economy of Urbicide}

53. During the Cold War, city planners and other urbanists contributed to a cultural project of atomic normalization that has proven surprisingly effective for more than half a century. What is more significant still is that the contribution of the city planning profession to this project must represent the ultimate expression of that project, in that America's willingness to acquiesce to the presence of nuclear weapons could surely find no more profound a form than in the notion that our society's very physical structure -- its cities -- would need to adapt to them.

54. The drive for urban security in the $21^{\text {st }}$ Century can also be said to serve a similar purpose: of normalizing the spectre of terrorism, of acculturating the public to the prospect of an endless war against it, and of manifesting physically society's acceptance of that war into its very built fabric.

55. If the democratic traditions of the United States have eroded dramatically in the past six years (and a number of observers have commented on its seeming drift towards fascism,, 57 then this erosion is in no small part due to the potent threat of urbicide that has been wielded relentlessly by the Bush Administration, which, at every opportunity, has reminded the public that another terrorist attack on American cities -- this time with weapons of mass destruction -- is a matter of "when, not if." As such, the built environment (and the efforts of those professionally associated with its creation and maintenance) becomes an essential ingredient of that potentiality by making the threat manifest through security measures ostensibly intended to make people feel more secure -- but which in practice quite likely have the opposite effect $\underline{\underline{5}}$.

56. In fact, the present, single-minded obsession with preventing terrorism serves the interests of the secure city very poorly. As Axworthy, Fallick and Ross $\underline{59}$ point out, along with the threat posed by global terrorism, the world is facing converging crises of economic inequality, environmental degradation, emerging pandemic diseases and unsustainable urbanism -- coupled with overcentralized and inflexible urban infrastructure ill-suited to 
rapid adaptability in the face of these crises -- and all these present a far more serious, general and ongoing threat to the world's cities than does terrorism. The authors call for a more holistic approach to security, one that: seeks to make cities more adaptable and resilient (i.e., through greater redundancy and decentralization of systems necessary to keep cities functioning, so that a breakdown in one will not cripple the whole); identifies and prepares for a fuller spectrum of risks and allocates resources more effectively; and redefines human security in terms of addressing some of the global inequities (poverty, ecological destruction; poor public health; war and other violent anti-terrorism measures) that -- not incidentally -- fuel terrorism.

57. With no such corresponding effort to address the injustices and geopolitical instability that give rise to terrorism, and without any questioning of the political agenda behind the imperatives of the state, planners advocating secure cities risk contributing to the neoconservative war machine that has, in its assault on Iraq and Afghanistan -- and endorsement of similar assaults by Israel on Lebanon and Gaza -- only served to fuel resentment throughout the Middle East.

58. The war on terror has also resulted in grossly misapplied resources at the expense of America's cities, the most tragic being the diversion of hundreds of millions of dollars from the Southeast Louisiana Urban Flood Control Project to fund the Iraq war, which may have contributed to hundreds of deaths following Hurricane Katrina in the fall of $2005^{60}$.

59. The nature of our anxieties may have changed in the decade-and-a-half since the end of the Cold War; yet we have inherited -- or perhaps never grew out of -- the "systems irrationality" that both drove the nuclear arms race and normalized the economic, political and social functions necessary to prepare for global annihilation.

60. The argument in this paper is composed of four parts: the first holds that in spite of its presumed purpose of creating a secure environment, urban security is in reality a discourse of fear and thus makes powerful contributions to the neoimperialism and militarism of the Bush Administration. The second is that such discourse is only made feasible by an intellectual, cultural and political epistemological vacuum that cripples both reason and public debate. Third, this knowledge vacuum is fundamentally, inherently and deliberately bound up with the threat of urbicide, the recent exemplar of which is the contested 9/11 event itself. The fourth argument is that, with the fear of urbicide being thus materialized in our built form and etherialized into our culture, our society is in danger of losing its hold on liberal democracy, and at the same time is becoming less capable of either discerning this erosion or questioning its origin. The national purpose must then become simultaneously irrational and almost impossible to challenge.

61. That which we fear most may be, in fact, the lesser of the threats facing the contemporary city, yet these ills go unaddressed, and indeed, are exacerbated by the very measures we hope will save us. Because it is at once so painful and so sacrosanct, the act of urban destruction that has been used to justify both the urban security project and the "war on terror" to which it is married remains an impenetrable lacuna, its origins and authors both unknown and, for all practical purposes, unknowable. The legacy of this unexplained destruction is a war without end; the razing of cities in the Middle East; a decline in civil liberties; and a fearful, uneasy relationship with the City and urban life.

62. Yet to question any of these tragic processes lies outside of acceptable discourse; thus we are bent on capturing in concrete, steel and glass a city made secure against nothing save self-knowledge, and the means by which to question the motives and purposes of the 
state.

Michael Dudley is a Research Associate with the Institute of Urban Studies at the University of Winnipeg (ius.uwinnipeg.ca), and teaches environmental psychology, city history and thesis preparation for the Faculty of Architecture at the University of Manitoba. He may be reached at m.dudley@uwinnipeg.ca

letter to the editors

\section{NOTES}

${ }_{1}^{1}$ Lewis Mumford The City in History: Its origins, its transformations and its prospects. New York: Harcourt, Inc., 1961, p. 45.

$\stackrel{2}{2}$ For a summary of this early literature see Joe Nasr "Planning Histories, Urban Futures, and the World Trade Center Attack" in Journal of Planning History Volume 2 no. 3, 2003, p. 195-211.

${ }^{3}$ Farhad Manjoo "Cityscape of Fear" in Salon.com, August $22^{\text {nd }} 2006$,

http://www.salon.com/news/feature/2006/08/22/architecture/index.html, paragraph 2

4 LawrenceVale "Securing Public Space" in Places Volume 17 no. 3, 2005, pp. 38-42.

${ }_{5}^{5}$ Deborah Natsios "National Security Sprawl" Cartome http://www.cartome.org/nss/Natsios-NSS.htm.

$\underline{6}$ Vale 2005, p. 41

${ }^{7}$ Natsios 2004. paragraph 20.

${ }^{8}$ quoted in Manjoo 2006, paragraph 3.

${ }^{9}$ Michael Q. Dudley "Sprawl as Strategy: City Planners Face the Bomb" in The Journal of Planning Education and Research Volume 20 no. 4, 2001, pp. 52-63.

10 Matthew Farish "Another Anxious Urbanism: Simulating Defense and Disaster in Cold War America" in Cities, war and terrorism: Towards an urban geopolitics, edited by Stephen Graham. Oxford: Blackwell, 2004.; Jennifer Light From Warfare to Welfare: Defense Intellectuals and Urban Problems in Cold War America. Baltimore: John Hopkins University Press, 2003.

11 Paul Boyer By the Bomb's Early Light: American Thought and Culture at the Dawn of the Atomic Age, New York, Pantheon Books, 1985.

12 See American Planning Association, American Planning Association Policy Guide on Security, 2005 http://www.planning.org/policyguides/pdf/security.pdf

13 Anthony Flint "Both safe and sorry: Second Generation Security Measures Could be Degrading What's Best About our Cities" in Planning Volume no. 6, 2005, p. 4-10; Witold Rybczynski "I Came, Eyesore, I Conquered: Perimeter Security is Ugly and May Not Keep us Safe"in Slate August 24th 2005, http://www.slate.com/id/2124886/?nav=navoa

14 Paul Windels "How Should our Cities Grow?" in Town and Country Planning 18 September 1950, p. 370.

15 Astrid Monson and Donald Monson "How Can we Disperse our Large Cities? Part II" American City Volume 66 no. 1, 1950 , p. 111.

16 Jeff Speck "An Alienating Monument to Surrender" in Metropolis: Urban Journal July 2005,

http://www.metropolismag.com/cda/story.php?artid=1489 
17 Martha T. Moore "Redesigns mask security barriers throughout USA." USA Today July $31^{\text {st }} 2006$, http://www.usatoday.com/news/nation/2006-07-31-national-security x.htm.

18 Manjoo 2006, paragraph 21.

$\underline{19}$ For a review of this literature see Dudley 2001. To give some idea of the prevalence of this literature in the 1950s: a dispersal bibliography published in a 1951 edition of The Bulletin of Atomic Scientists ran to 87 entries see note 31 below.

${ }^{20}$ Federal Leadership to Reduce Vulnerability, Project East River Part II-B. New York: Associated Universities, Inc., 1952.

21 Margot Henriksen, Dr. Strangelove's America: Society and Culture in the Atomic Age. Berkeley, University of California Press, 1997, pp. 193-239.

$\underline{22}$ Nigel Taylor, "Anglo-American Town Planning Theory Since 1945: Three Significant Developments but no Paradigm Shifts" in Planning Perspectives Volume 14, 1999, p. 330.

$\underline{23}$ Federal Civil Defense Administration, Cue for Survival: Operation Cue A.E.C. Test Site May 5th, 1955, a Report by the Federal Civil Defense Administration. Washington D.C., United States Government Printing Office, 1955.

$\underline{24}$ Boyer 1985

$\underline{25}$ Lee Clark, Mission Improbable: Using Fantasy Documents to Tame Disaster. Chicago: University of Chicago Press, 1999.

$\underline{26}$ Ibid.

$\underline{27}$ Ibid.

$\underline{28}$ National Security Resources Board, Department of Defense, and the Federal Civil Defense Administration Project East River Volume V: Reduction of Urban Vulnerability. New York: Associated Universities, Inc, 1952.

$\underline{29}$ Robert J. Lifton and Richard A. Falk Indefensible Weapons, The Political and Psychological Case Against Nuclearism. New York, Basic Books, Inc., 1983.

$\underline{30}$ Boyer p. 14.

${ }^{31}$ Robert J. Lifton and Greg Mitchell Hiroshima in America, Fifty Years of Denial. New York, G.P. Putnam's Sons, 1995, p. 208

32 American Institute of Planners "Defense Considerations in City Planning" in Bulletin of the Atomic Scientists Volume 9, no 7, 1953, p. 268 emphasis added.

$\underline{33}$ As evinced by Berthold Altmann and Harry Moskowitz "Dispersal - A Selected Reading List" in Bulletin of the Atomic Scientists Volume 7, no 9, 1951, pp. 280-284.

34 Moore 2006.

35 Oscar Newman Defensible Space New York: McMillan, 1972.

${ }^{36}$ Walter Thabit "Planning and civil defense" in Journal of the American Institute of Planners Volume 25 no. 1, 1959, p. 36.

37 "Institute Affairs, Planners and the National Emergency" in Journal of the American Institute of Planners, Fall 1950 p. 200.

${ }^{38}$ Ralph Lapp "Eight Years Later" in Bulletin of the Atomic Scientists Volume 9 no. 7, 1953, pp. 234-236.

399 American Planning Association 2005.

$\underline{40}$ "Homeland Security Threatens Civil Liberties" in Project Censored 2004 http://www.projectcensored.org/publications/2004/2.html, paragraphs 4 \& 8 . 
$\underline{41}$ see Patsy Healey Collaborative Planning: Shaping Places in Fragmented Societie, Vancouver: UBC Press, 1997.

$\underline{42}$ There is widespread speculation that DHS awarded the military contractor Kellogg-Brown a no-bid contract to construct domestic detention camps to incarcerate large numbers of Americans in the case of an unspecified declared emergency. Nat Parry "Bush's mysterious 'new programs.'" Consortiumnews.com February 21, 2006 http://www.consortiumnews.com/2006/022106a.html.

$\underline{43}$ see Planners Network Steering Committee Urban Planners Oppose the War in Iraq March $20^{\text {th, }} 2003$ http://www.plannersnetwork.org/publications/statement iraq.html

$\underline{44}$ Edward Said quoted in Stephen Graham "Cities and the 'War on Terror'" in International Journal of Urban and Regional Research Volume 30, 2006, pp. 255-276.

$\underline{45}$ Graham 2006

46 Mitchell Gray and Elvin Wyly "The terror city hypothesis" in Violent geographies: Fear, Terror and Political Violence edited by Derek Gregory and Allan Pred. London: Routledge, 2006.

47 Samuel P. Huntington The Clash of Civilizations and the Remaking of World Order New York: Simon \& Schuster, 2002.

48 Greg Mitchell "A Hole in History: America Suppresses the Truth about Hiroshima" in The Progressive August 1 1995, pp. $22-26$.

$\underline{49}$ Kyo MacLear Beclouded Visions: Hiroshima-Nagasaki and the Art of Witness Albany, State University of New York Press, 1999 p. 42.

50 Gar Alperovitz The Decision to Use the Atomic Bomb and the Architecture of an American Myth, New York: Alfred Knopf, 1995.

51 Mitchell 1995.

52 See the claims and counter claims of the "9/11 Truth Movement" (http://www.911truth.org/) and its detractors, e.g., "Debunking 911 Myths" Popular Mechanics March 2005. http://www.popularmechanics.com/technology/military law/1227842.html

53 David Brock The Republican Noise Machine: Right-Wing Media and How it Corrupts Democracy New York: Crown, 2004.

54 Joshua Micha Marshall "The Post-Modern President: Deception, Denial, and Relativism: What the Bush Administration Learned from the French" Washington Monthly September 2003. http://www.washingtonmonthly.com/features/2003/0309.marshall.html

55 For example in July 2005, the New York Times columnist Thomas Friedman called for a blacklist of those who suggested that "Western imperialism" and war-making might arouse terrorist acts, calling such discourse "hate speech". Thomas Friedman "Giving the Hatemongers No place to Hide" in The New York Times July $22^{\text {nd }} 2005$ http://www.nytimes.com/2005/07/22/opinion/22friedman.html?ex=1279684800\&en=17fb5beb19b09d86\&ei=5090\&partner=rssuserland $\underline{\text { \&emc }=\text { rss }}$

56 Gray and Wyly 2006.

${ }^{57}$ for example, Chris Hedges American Fascists : The Christian Right and the War On America. New York: Free Press.

$\underline{58}$ Manjoo 2006

59 Dr. Lloyd Axworthy, Arthur L. Fallick and Kelly Ross The Secure City (The World Urban Forum 2006: Vancouver Working Group Discussion Paper). Vancouver: The Liu Institute for Global Issues at the University of British Columbia, March 2005.

60 Will Bunch "Did New Orleans catastrophe have to happen? 'Times-Picayune' had repeatedly raised federal spending issues" in Editor \& Publisher August 30 2005 http://www.editorandpublisher.com/eandp/news/article display.jsp?vnu content id=1001051313 